\title{
STEROIDAL GLYCOSIDES FROM THE SEEDS OF HYOSCYAMUS NIGER L. AND THEIR ANTIFUNGAL ACTIVITY
}

\author{
Irina Lunga, ${ }^{\text {a* }}$ Pavel Chintea, ${ }^{a}$ Stepan Shvets, ${ }^{a}$ Anna Favel ${ }^{b}$ and Cosimo Pizza ${ }^{c}$ \\ ${ }^{a}$ Institute of Genetics and Physiology of Plants, Academy of Sciences of Moldova,Padurii 20, 2004, Chisinau, Moldova \\ ${ }^{b}$ Laboratory of Botany, Cryptogamy and Cellular Biology, Faculty of Pharmacy, 27 Bd. J. Moulin 13385 Marseille Cedex 5, \\ France \\ ${ }^{c}$ Department of Pharmaceutical Sciences, University of Salerno, Ponte Don Melillo, 84084, Fisciano, Salerno, Italy \\ *lunga_irina@yahoo.com, tel. 37322 555259, fax 37322556180
}

\begin{abstract}
Phytochemical analysis of the seeds of Hyocyamus niger L. (Solonaceae) resulted in the isolation of six steroidal glycosides, two furostanol $(\mathbf{1}, \mathbf{2})$ and four spirostanol saponins $(\mathbf{3}, \mathbf{4}, \mathbf{5}, \mathbf{6})$, which were found in this plant for the first time. The structures of these compounds were determined by detailed analysis of their spectral data, including two-dimensional NMR spectroscopy and MS spectroscopy. The antifungal activity of a crude steroidal glycoside extract, fractions of spirostanoles and individual glicosides was investigated in vitro against a panel of human pathogenic fungi, yeasts as well as dermatophytes and filamentous species.
\end{abstract}

Keywords: Hyoscyamus niger L., steroidal glycosides, antifungal activity.

\section{INTRODUCTION}

The genus Hyocyamus belongs to the family Solonaceae and is widely distributed in Europe and Asia [1]. As a weed of cultivation it now grows also in North America and Brazil. The leaves or roots eaten produce maniacal delirium, if nothing worse. It is poisonous in all its parts, and neither drying nor boiling destroys the toxic principle.

Previously this plant never has been studied on steroidal glycosides. The chief constituent of Hyoscyamus niger L. (black henbane) was earlier reported by us [2]. The antifungal activity of steroidal saponins, particularly against agricultural pathogens, has been known for a long time [3-6], while other reported activities for this class of compounds include antitumor, hypoglycemic, immunoregulatory, and cardiovascular disease prevention and treatment [7].

Since several steroidal glycosides exhibit fungistatic or fungicidal activity [8,9], extract of seeds has been included in our screening programme for novel antifungal agents of plant origin. Its activity has been investigated in vitro against a panel of human pathogenic fungi, yeasts as well as dermatophytes and filamentous species. The antifungal activity of a spirostanoid fraction and of the individual glycosides, has been also evaluated to identify the bioactive compound.

\section{RESULTS AND DISCUSSION}

The ${ }^{1} \mathrm{H}$ NMR spectrum of $\mathbf{1}$ showed signals for four steroidal methyl groups at $\delta 0.89$ (3H, s, Me-19), 0.84 (3H, s, Me-18), $1.02(3 \mathrm{H}, \mathrm{d}, \mathrm{Me}-21), 0.98(3 \mathrm{H}, \mathrm{d}, \mathrm{Me}-27)$, two methine proton signals at $\delta 3.68(1 \mathrm{H}, \mathrm{m}, \mathrm{H}-3)$ and $4.39(1 \mathrm{H}$, $\mathrm{m}, \mathrm{H}-16)$ indicative of secondary alcoholic functions, two methylene proton signals at $\delta 3.41(1 \mathrm{H}, \mathrm{m}, \mathrm{H}-26 \mathrm{a})$ and 3.29 $(1 \mathrm{H}, \mathrm{m}, \mathrm{H}-26 \mathrm{~b})$, ascribable to a primary alcoholic function, and four anomeric protons at $\delta 4.40(1 \mathrm{H}, \mathrm{d}, J=7.5 \mathrm{~Hz})$, $4.56(1 \mathrm{H}, \mathrm{d}, J=7.5 \mathrm{~Hz}), 4.69(1 \mathrm{H}, \mathrm{d}, J=7.5 \mathrm{~Hz})$ and $4.26(1 \mathrm{H}, \mathrm{d}, J=7.5 \mathrm{~Hz})$. The ${ }^{13} \mathrm{C}$ NMR spectrum displayed signals ascribable to a hemiketal function at $\delta 113.8$, two secondary carbons bearing alcoholic functions at $\delta 79.2$ and 82.4, and one primary carbon bearing the same functionality at $\delta 75.9$, suggesting the occurrence of a glycoside furostanol skeleton. It was evident from the ${ }^{1} \mathrm{H}$ and ${ }^{13} \mathrm{C}$ NMR data that the sugar chain at $\mathrm{C}-3$ of $\mathbf{1}$ consisted of three sugar units. The chemical shifts of all the individual protons of the three sugar units were ascertained from a combination of 1DTOCSY and DQF-COSY spectral analysis, and the ${ }^{13} \mathrm{C}$ chemical shifts of their corresponding carbons could be assigned unambiguously from the HSQC spectrum. These data showed the presence of one $\beta$-galactopyranosyl unit $(\delta 4.40)$ and two $\beta$-glucopyranosyl unit ( $\delta 4.56$ and 4.69). A glycosidation shifts were observed for $\mathrm{C}-4$ gal $(\delta 80.3)$ and for $\mathrm{C}-2_{\text {glc }}(\delta$ 85.9). The HMBC spectrum showed key correlation peaks between the proton signal at $\delta 4.40\left(\mathrm{H}-1_{\text {gal }}\right)$ and the carbon resonance at $\delta 79.2\left(\mathrm{C}-3\right.$ of the aglycon), the proton signal at $\delta 4.56\left(\mathrm{H}-1_{\mathrm{glc}}\right)$ and the carbon resonance at $\delta 80.3\left(\mathrm{C}-4_{\mathrm{gal}}\right)$, the proton signal at $\delta 4.69\left(\mathrm{H}-1_{\mathrm{glcl}}\right)$ and the carbon resonance at $\delta 85.9\left(\mathrm{C}-2_{\mathrm{glc}}\right)$, the proton signal at $\delta 4.26\left(\mathrm{H}-1_{\mathrm{glcI}}\right)$ and the carbon resonance at $\delta 75.9$ (C-26 of the aglycon). 
${ }^{13} \mathrm{C}$ NMR spectral data (300 $\left.\mathrm{MHz}, \mathrm{CD}_{3} \mathrm{OD}\right)$ of saponins (1-3)

\begin{tabular}{|c|c|c|c|}
\hline Carbon & 1 & 2 & 3 \\
\hline 1 & 37.9 & 38.3 & 38.2 \\
\hline 2 & 30.4 & 30.5 & 30.6 \\
\hline 3 & 79.2 & 78.9 & 79.3 \\
\hline 4 & 34.9 & 34.8 & 35.2 \\
\hline 5 & 46.0 & 46.0 & 45.6 \\
\hline 6 & 32.9 & 33.0 & 32.9 \\
\hline 7 & 32.7 & 32.7 & 32.6 \\
\hline 8 & 34.6 & 34.7 & 36.3 \\
\hline 9 & 55.7 & 55.7 & 55.6 \\
\hline 10 & 36.0 & 36.0 & 36.4 \\
\hline 11 & 30.9 & 22.0 & 21.8 \\
\hline 12 & 40.8 & 40.8 & 40.7 \\
\hline 13 & 55.9 & 55.9 & 41.5 \\
\hline 14 & 57.3 & 57.4 & 57.4 \\
\hline 15 & 32.4 & 32.8 & 32.4 \\
\hline 16 & 82.4 & 82.2 & 82.0 \\
\hline 17 & 64.9 & 64.9 & 63.5 \\
\hline 18 & 16.5 & 16.5 & 16.9 \\
\hline 19 & 12.3 & 12.8 & 12.7 \\
\hline 20 & 41.0 & 41.0 & 42.5 \\
\hline 21 & 16.0 & 16.6 & 14.6 \\
\hline 22 & 113.8 & 113.8 & 110.4 \\
\hline 23 & 37.4 & 37.3 & 32.5 \\
\hline 24 & 28.9 & 30.9 & 29.5 \\
\hline 25 & 34.8 & 36.4 & 31.1 \\
\hline 26 & 75.9 & 75.8 & 67.4 \\
\hline 27 & 16.8 & 16.2 & 16.6 \\
\hline $1^{\prime}$ & 102.7 & 102.3 & 102.7 \\
\hline $2^{\prime}$ & 73.0 & 72.8 & 73.1 \\
\hline $3^{\prime}$ & 75.3 & 75.1 & 75.4 \\
\hline $4^{\prime}$ & 80.3 & 79.0 & 79.0 \\
\hline $5^{\prime}$ & 79.3 & 79.3 & 75.0 \\
\hline $6^{\prime}$ & 60.6 & 62.6 & 60.9 \\
\hline $1 "$ & 105.0 & 105.7 & 105.7 \\
\hline $2 "$ & 85.9 & 75.2 & 75.4 \\
\hline $3 "$ & 78.0 & 78.2 & 78.0 \\
\hline $4 "$ & 75.6 & 78.0 & 71.8 \\
\hline $5 "$ & 71.6 & 71.6 & 78.0 \\
\hline 6" & 63.0 & 62.9 & 63.0 \\
\hline $1^{\prime \prime \prime \prime}$ & 106.3 & & \\
\hline $2^{\prime \prime \prime}$ & 76.4 & & \\
\hline $3^{\prime \prime \prime}$ & 75.8 & & \\
\hline $4^{\prime \prime \prime}$ & 77.9 & & \\
\hline $5^{\prime \prime \prime}$ & 70.5 & & \\
\hline $6^{\prime \prime \prime}$ & 61.4 & & \\
\hline $1^{\prime \prime \prime \prime \prime}$ & 104.7 & 104.1 & \\
\hline $2^{\prime \prime \prime \prime \prime}$ & 74.9 & 74.8 & \\
\hline $3^{\prime \prime \prime \prime \prime}$ & 78.4 & 78.0 & \\
\hline $4^{\prime \prime \prime \prime \prime}$ & 71.5 & 71.4 & \\
\hline $5^{\prime \prime \prime \prime \prime}$ & 71.6 & 71.2 & \\
\hline $6^{\prime \prime \prime \prime}$ & 62.8 & 63.0 & \\
\hline
\end{tabular}


On the basis of this evidence, the structure of compound 1 was established as 3-O- $\beta$-D-glucopyranosyl-

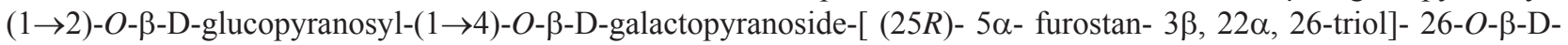
glucopyranoside.

Comparison of the ${ }^{1} \mathrm{H}$ and ${ }^{13} \mathrm{C}$ NMR spectra of $\mathbf{1}$ and $\mathbf{2}$ indicated an identical aglycon moiety. Compound $\mathbf{2}$ was shown to contain three sugar residues from the HSQC spectrum. The anomeric protons at $\delta 4.39(1 \mathrm{H}, \mathrm{d}, J=7.5 \mathrm{~Hz})$, $4.54(1 \mathrm{H}, \mathrm{d}, J=7.5 \mathrm{~Hz})$ and $4.27(1 \mathrm{H}, \mathrm{d}, J=7.5 \mathrm{~Hz})$ giving correlations with carbon signals at $\delta 102.3,105.7$, and 104.1 , respectively, were assigned to anomeric protons of $\beta$-galactopyranose and two molecules of $\beta$-glucopyranose, respectively.

Table 2

In vitro antifungal activity of extract, spirostanoid fraction, individual glicosides, given as minimum fungicidal concentrations $(\mu \mathrm{g} / \mathrm{mL})$

\begin{tabular}{|c|c|c|c|c|c|c|c|c|c|}
\hline \multirow[b]{2}{*}{ Species } & \multirow[b]{2}{*}{ Extract } & \multirow{2}{*}{$\begin{array}{l}\text { Spirost. } \\
\text { fraction }\end{array}$} & \multicolumn{6}{|c|}{ Compounds } & \multirow{2}{*}{$\begin{array}{l}\text { Ref. } \\
\text { Drug.* }\end{array}$} \\
\hline & & & 1 & 2 & 3 & 4 & 5 & 6 & \\
\hline \multicolumn{10}{|c|}{ Yeast } \\
\hline $\begin{array}{c}\text { Candida albicans } \\
\text { ATCC } 90029\end{array}$ & 0.125 & 50 & $>100$ & $>100$ & 25 & 25 & 25 & 25 & 1.56 \\
\hline $\begin{array}{c}\text { C.albicans } \\
38248\end{array}$ & 0.125 & 50 & 100 & 100 & 12.5 & 12.5 & 12.5 & 12.5 & 1.56 \\
\hline $\begin{array}{l}\text { C.albicans } \\
40109\end{array}$ & 0.125 & 50 & $>100$ & $>100$ & 25 & 25 & 25 & 12.5 & 1.56 \\
\hline $\begin{array}{c}\text { C. tropicalis IP } \\
1275-81 \\
\end{array}$ & 0.06 & 25 & $>100$ & $>100$ & 12.5 & 12.5 & 12.5 & 12.5 & 12.5 \\
\hline $\begin{array}{l}\text { C. parapsilosis } \\
\text { ATCC } 220\end{array}$ & 0.06 & 50 & $>100$ & $>100$ & 12.5 & 12.5 & 12.5 & 12.5 & 3.12 \\
\hline $\begin{array}{c}\text { C. glabrata } \\
\text { ATCC } 90030\end{array}$ & 0.06 & 25 & 100 & 100 & 12.5 & 12.5 & 12.5 & 12.5 & 0.78 \\
\hline C. kefir Y0106 & $>1$ & $>100$ & N.T. & N.T. & $>100$ & $>100$ & $>100$ & 100 & 0.78 \\
\hline $\begin{array}{c}\text { C. kruse ATCC } \\
6258\end{array}$ & 0.25 & $>100$ & $>100$ & $>100$ & 25 & 25 & 25 & 25 & 3.12 \\
\hline $\begin{array}{c}\text { C. lusitaniae CBS } \\
6936\end{array}$ & $>1$ & $>100$ & N.T. & N.T. & $>100$ & $>100$ & $>100$ & 100 & 1.56 \\
\hline $\begin{array}{c}\text { Cryptococcus } \\
\text { neoformans }\end{array}$ & 0.06 & 25 & $>100$ & $>100$ & 12.5 & 12.5 & 12.5 & 12.5 & 0.78 \\
\hline \multicolumn{10}{|c|}{ Dermatophytes } \\
\hline $\begin{array}{l}\text { Trichophyton } \\
\text { rubrum }\end{array}$ & 0.5 & 7.8 & $>100$ & $>100$ & 6.25 & 6.25 & 6.25 & 3.12 & 1.56 \\
\hline $\begin{array}{c}\text { Trichophyton } \\
\text { mentagraphytes }\end{array}$ & 0.5 & 15.6 & $>100$ & $>100$ & 6.25 & 6.25 & 6.25 & 6.25 & 1.56 \\
\hline $\begin{array}{c}\text { Trichophyton } \\
\text { soudanense }\end{array}$ & 1.0 & 15.6 & N.T. & N.T. & 12.5 & 12.5 & 12.5 & 12.5 & 1.56 \\
\hline Microsporum canis & 0.5 & 7.8 & $>100$ & $>100$ & 6.25 & 6.25 & 6.25 & 3.12 & 1.56 \\
\hline M. gypseum & 0.5 & 7.8 & $>100$ & $>100$ & 6.25 & 6.25 & 6.25 & 3.12 & 1.56 \\
\hline $\begin{array}{l}\text { Epidermophyton } \\
\text { floccosum }\end{array}$ & 0.5 & 7.8 & $>100$ & $>100$ & 6.25 & 6.25 & 6.25 & 6.25 & 1.56 \\
\hline \multicolumn{10}{|c|}{ Filamentous fungi } \\
\hline $\begin{array}{l}\text { Aspergillus } \\
\text { funigatus }\end{array}$ & 10 & 100 & N.T. & N.T. & 75 & 75 & 75 & 50 & 1.56 \\
\hline A. flavus & 7.5 & 31.2 & N.T. & N.T. & 6.25 & 6.25 & 6.25 & 3.12 & 0.78 \\
\hline $\begin{array}{c}\text { Scopulariopsiss } \\
\text { brevicaulis }\end{array}$ & 15 & 250 & N.T. & N.T. & 125 & 125 & 125 & 100 & 3.12 \\
\hline
\end{tabular}

*The reference antifungal agents were amphotericin B and ketoconazole for yeasts and filamentous fungi, and dermatophytes, respectively.

The point of attachment of these sugars was then deduced from the HMBC of 2 which showed a cross peak between the $\mathrm{H}-1 \mathrm{Gal}$ at $\delta 4.39$ and $\mathrm{C}-3$ of the aglycon at $\delta$ 78.9. Other correlations between H-1 GlcI at $\delta 4.27$ and C-26 of the aglycon at $\delta$ 75.8; and between $\mathrm{H}-1 \mathrm{Glc}$ at $\delta 4.54$ and $\mathrm{C}-4 \mathrm{Gal}$ at $\delta$ 79.0. On the basis of the above results the 
structure of 2 was determined as 3-O- $\beta$-D-glucopyranosyl - $(1 \rightarrow 4)-O-\beta$-D-galactopyranoside- $[(25 R)-5 \alpha-$ furostan- $3 \beta$, $22 \alpha$, 26-triol]-26-O- $\beta$-D-glucopyranoside. The presented chemical structures have been previously reported in Petunia hybrida by Shvets et al. in 1995 [10].

The ${ }^{1} \mathrm{H}$ NMR spectrum of 3 showed signals for four methyl groups at $\delta 0.89$ (3H, s, Me-19), $0.82(3 \mathrm{H}, \mathrm{s}, \mathrm{Me}-18)$, $1.00(3 \mathrm{H}, \mathrm{d}, \mathrm{Me}-21), 1.12(3 \mathrm{H}, \mathrm{d}, \mathrm{Me}-27)$. The HMBC correlation of methyl groups clearly showed that the aglycon moiety was similar of compound $\mathbf{1}$ and was identified as (25R)- $5 \alpha$-spirostan-3 $\beta$, 26-diol. Glycoside spirostanol skeleton is suggested according to the presence of primary alcoholic function at $\delta 67.7$ (C-26). The ${ }^{1} \mathrm{H}$ NMR spectrum showed signals for two anomeric protons at $\delta 4.39(1 \mathrm{H}, \mathrm{d}, J=7.5 \mathrm{~Hz}), 4.56(1 \mathrm{H}, \mathrm{d}, J=7.5 \mathrm{~Hz})$. The HMBC, 1D-TOCSY and DQF-COSY spectral analysis of the sugar moiety was similar to those of compound 2 . According to these data, compound 3 was assigned the structure 3-O- $\beta$-D-glucopyranosyl - $(1 \rightarrow 4)-O-\beta$-D-galactopyranoside- $(25 R)$ - $5 \alpha-$ spirostan - 3 $\beta$-ol, described with Gutsu et al. in year 1987 from Capsicum annum [11].

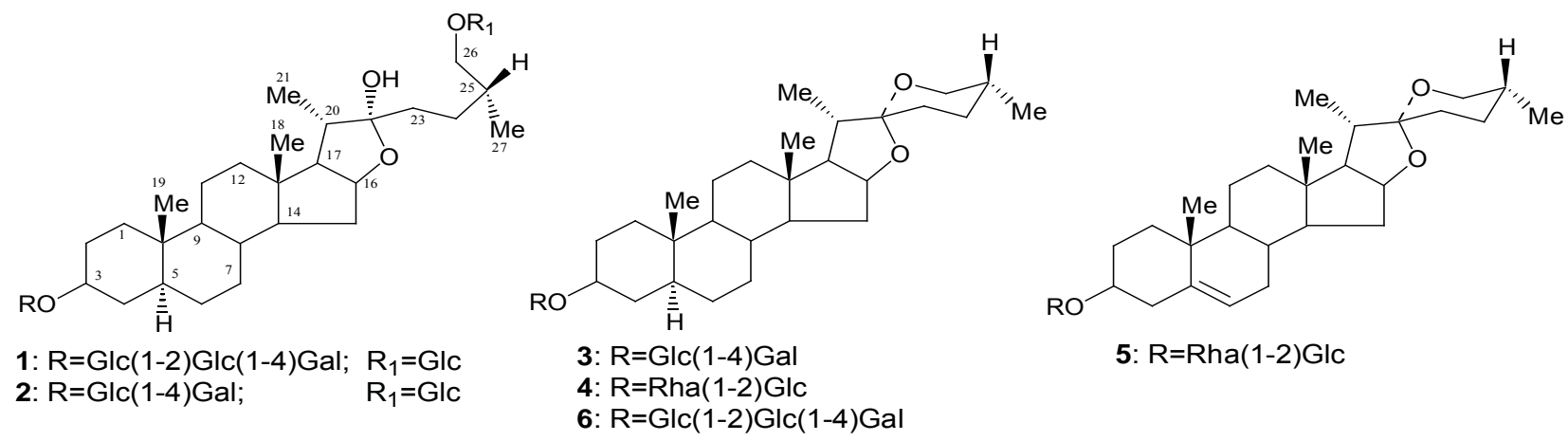

The structures of compounds 4, 5 and $\mathbf{6}$ were elucidated by us earlier [2]. For compound $4-3-O-\alpha-\mathrm{L}-$ rhamnopyranosyl- $(1 \rightarrow 2)$ - $\beta$-D-glucopyranoside-(25R)- $5 \alpha$-spirostan - $3 \beta$-ol; for compound 5- $O$ - $\alpha$-L-rhamnopyranosyl$(1 \rightarrow 2)$ - $\beta$ - D-glucopyranoside -(25R)- 5-ene -spirostan -3 $\beta$-ol and for compound 6 -3-O- $\beta$-D-glucopyranosyl-( $1 \rightarrow 2)$ $\beta$-D-glucopyranosyl - $(1 \rightarrow 4)-O$ - $\beta$-D-galactopyranoside- $(25 R)$ - $5 \alpha$ - spirostan - $3 \beta$-ol.

Table 2 shows that extract had a broad spectrum of antifungal activity in vitro. It was active against all the tested strains except for two (C. lusitaniae and C. kefir). The best antifungal activity was observed against dermatophytes and against yeasts, to a lesser extent. The least sensitive yeast species were C.tropicalis, C. parapsilosis, C. glabrata and Cryptococcus neoformans. Its activity against filamentous fungi was weak to moderate. The furostanol glycosides were devoid of any antifungal activity. The antifungal activity was found to reside entirely in the spirostanol fraction and individual glycosides with minimum inhibitory concentrations (MIC) from 7.8 to $250 \mu \mathrm{g} / \mathrm{mL}$. The MICs for the dermatophytes were between 3.12 and $125 \mu \mathrm{g} / \mathrm{mL}$. The most sensitive filamentous species was A. flavus (MIC = 3.12 $\mu \mathrm{g} / \mathrm{mL})$.

\section{EXPERIMENTAL}

The seeds of Hyoscyamus niger L. have been collected in the scientific research field of the Institute of Scientific Researches and Technological Constructions for Tobacco and Tobacco Products of Moldova in November 2001 year. The voucher specimen has been deposited in laboratory of botanic by leading of Doctor in Biology Kalkei E.D. The air-dried seeds were extracted three times in $50^{\circ} \mathrm{C}$ with water saturated n-buthanol. After evaporation of n-buthanol, water extract was purified with chloroform and finally the steroidal glycosides were crystallised in acetone. The sum of steroidal saponins has been obtained in yellow powder in the yield 3,7\%. Extract has been chromatographied on silica gel column $(30-500 \mathrm{~mm}, 60-100 \mu \mathrm{m}$, Merck). The column was eluted with the system of solvents chloroformmethanol-water $(8: 2: 0 \rightarrow 20: 10: 1)$. The polar subfractions were obtained, which was further separated on a $\mathrm{C}_{18}$ column (7,8x300mm, LiChroprep RP18, 25-40 $\mu \mathrm{m}$, XTerra Waters) using a MeOH/ $\mathrm{H}_{2} \mathrm{O}(60-65 \% \mathrm{MeOH})$ gradient. Three single compounds were obtained.

Structures were determined by $1 \mathrm{D}-\left({ }^{1} \mathrm{H},{ }^{13} \mathrm{C}\right.$, TOCSY), 2D (COSY, HSQC, HMBC) NMR, ESIMS and HRMS experiments. Samples were analyzed by matrix assisted laser desorption ionization (MALDI) mass spectrometry. ESIMS analyses were performed using a ThermoFinnigan (San Josè, CA, USA) LCQ Deca XP Max ion trap mass spectrometer equipped with Xcalibur software. NMR experiments in $\mathrm{CD}_{3} \mathrm{OD}$ were performed on a Bruker DRX-600 spectrometer at $300 \mathrm{~K}$. Column chromatography was performed over Silica gel (Merck). HPLC separations were carried out on a

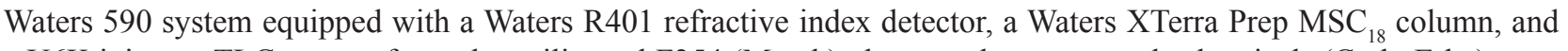
a U6K injector. TLC was performed on silica gel F254 (Merck) plates, and reagent grade chemicals (Carlo Erba) were used throughout.

1. HRMS, m/z 1081.643 [calculated for $\left.\mathrm{C}_{51} \mathrm{H}_{84} \mathrm{O}_{24}(\mathrm{M})^{+}\right]$; $919.6[\mathrm{M}-162]^{+} ; 757[\mathrm{M}-2 \mathrm{x} 162]^{+}$; ${ }^{1} \mathrm{H}$ NMR (aglycon) 


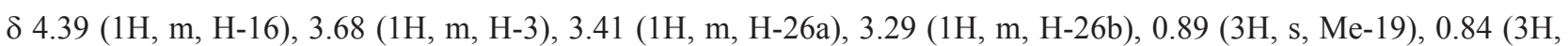
s, Me-18), 1.02 (3H, d, H-21), 0.98 (3H, d, Me-27). (sugars) 84.40 (d, J=7.4 Hz, H-1Gal), 3.60 (dd, J=7.4 and 9.0 Hz, $\mathrm{H}-2 \mathrm{Gal}$ ), 3.53 (dd, $J=4.0$ and $9.0 \mathrm{~Hz}, \mathrm{H}-3 \mathrm{Gal}$ ), 4.02 (dd, $J=2.5$ and $4.0 \mathrm{~Hz}, \mathrm{H}-4 \mathrm{Gal}$ ), 3.69 (ddd, $J=2.5,2.5 \mathrm{and} 4.5 \mathrm{~Hz}$, H-5Gal), 3.62 (dd, $J=4.5$ and $12.0 \mathrm{~Hz}, \mathrm{H}-6 \mathrm{aGal}$ ), 3.95 (dd, $J=2.5$ and $12.0 \mathrm{~Hz}, \mathrm{H}-6 \mathrm{bGal}), 4.56$ (d, $J=7.5 \mathrm{~Hz}, \mathrm{H}-1 \mathrm{Glc}$ ), 3.55 (dd, $J=7.5$ and $9.0 \mathrm{~Hz}, \mathrm{H}-2 \mathrm{Glc}$ ), 3.60 (dd, $J=9.0$ and $9.0 \mathrm{~Hz}, \mathrm{H}-3 \mathrm{Glc}$ ), 3.35 (dd, $J=9.0$ and 9.0 Hz, H-4Glc), 3.25 (ddd, $J=2.5,4.5$ and $9.0 \mathrm{~Hz}, \mathrm{H}-5 \mathrm{Glc}$ ), 3.60 (dd, $J=4.5$ and $11.5 \mathrm{~Hz}, \mathrm{H}-6 \mathrm{aGlc}$ ), 3.93 (dd, $J=2.5$ and 11.5 Hz, H-6bGlc), 4.69 (d, J=7.5 Hz, H-1GlcI), 3.29 (dd, $J=7.5$ and $9.0 \mathrm{~Hz}, \mathrm{H}-2 \mathrm{GlcI}), 3.36$ (dd, $J=9.0$ and 9.0 Hz, H-3GlcI), 3.40 (dd, $J=9.0$ and $9.0 \mathrm{~Hz}, \mathrm{H}-4 \mathrm{GlcI}$ ), 3.42 (ddd, $J=2.5,4.5$ and $9.0 \mathrm{~Hz}, \mathrm{H}-5 \mathrm{GlcI}$ ), 3.69 (dd, $J=4.5$ and $11.5 \mathrm{~Hz}, \mathrm{H}-6 \mathrm{GGlcI}$ ), 3.82 (dd, $J=2.5$ and $11.5 \mathrm{~Hz}, \mathrm{H}-6 \mathrm{bGlcI}$ ), 4.26 (d, $J=7.5 \mathrm{~Hz}, \mathrm{H}-1 \mathrm{GlcII}), 3.20$ (dd, $J=7.5$ and $9.0 \mathrm{~Hz}, \mathrm{H}-2 \mathrm{GlcII}), 3.37$ (dd, $J=9.0$ and $9.0 \mathrm{~Hz}, \mathrm{H}-3 \mathrm{GlcII}$ ), 3.33 (dd, $J=9.0$ and $9.0 \mathrm{~Hz}, \mathrm{H}-4 \mathrm{GlcII}$ ), 3.28 (ddd, $J=2.5,4.5$ and $9.0 \mathrm{~Hz}, \mathrm{H}-5 \mathrm{GlcII}$ ), 3.69 (dd, $J=4.5$ and $11.5 \mathrm{~Hz}, \mathrm{H}-6 \mathrm{GGlcII}), 3.85$ (dd, $J=2.5$ and $11.5 \mathrm{~Hz}, \mathrm{H}-6 \mathrm{bGlcII})$. For ${ }^{13} \mathrm{C}$ NMR see Table 1.

2. HRMS, $m / z$ 919.342 [calculated for $\mathrm{C}_{45} \mathrm{H}_{74} \mathrm{O}_{19}(\mathrm{M})^{+}$]; $757.53[\mathrm{M}-162]^{+} ; 595[\mathrm{M}-2 \mathrm{x} 162]^{+} ;{ }^{1} \mathrm{H}$ NMR (aglycon) $\delta$ 4.38 (1H, m, H-16), 3.68 (1H, m, H-3), 3.41 (1H, m, H-26a), 3.29 (1H, m, H-26b), 0.89 (3H, s, Me-19), 0.84 (3H, s, Me18), 1.02 (3H, d, H-21), 0.98 (3H, d, Me-27). (sugars) $\delta 4.39$ (d, J=7.4 Hz, H-1Gal), 3.52 (dd, J=7.4 and 9.0 Hz, H-2Gal), 3.53 (dd, $J=4.0$ and $9.0 \mathrm{~Hz}, \mathrm{H}-3 \mathrm{Gal}$ ), 4.08 (dd, $J=2.5$ and $4.0 \mathrm{~Hz}, \mathrm{H}-4 \mathrm{Gal}), 3.69$ (ddd, $J=2.5,2.5 \mathrm{and} 4.5 \mathrm{~Hz}, \mathrm{H}-5 \mathrm{Gal}$ ), 3.70 (dd, $J=4.5$ and $12.0 \mathrm{~Hz}, \mathrm{H}-6 \mathrm{aGal}), 3.92$ (dd, $J=2.5$ and $12.0 \mathrm{~Hz}, \mathrm{H}-6 \mathrm{bGal}), 4.54$ (d, J=7.5 Hz, H-1Glc), 3.55 (dd, $J=7.5$ and $9.0 \mathrm{~Hz}, \mathrm{H}-2 \mathrm{Glc}$ ), 3.38 (dd, $J=9.0$ and $9.0 \mathrm{~Hz}, \mathrm{H}-3 \mathrm{Glc}$ ), 3.35 (dd, $J=9.0$ and $9.0 \mathrm{~Hz}, \mathrm{H}-4 \mathrm{Glc}$ ), 3.24 (ddd, $J=2.5$, 4.5 and $9.0 \mathrm{~Hz}, \mathrm{H}-5 \mathrm{Glc}$ ), 3.69 (dd, $J=4.5$ and $11.5 \mathrm{~Hz}, \mathrm{H}-6 \mathrm{GGlc}$ ), 3.89 (dd, $J=2.5$ and 11.5 Hz, H-6bGlc), 4.27 (d, $J=7.5$ Hz, H-1GlcI), 3.20 (dd, $J=7.5$ and $9.0 \mathrm{~Hz}, \mathrm{H}-2 \mathrm{GlcI}$ ), 3.37 (dd, $J=9.0$ and $9.0 \mathrm{~Hz}, \mathrm{H}-3 \mathrm{GlcI}$ ), 3.32 (dd, $J=9.0$ and $9.0 \mathrm{~Hz}$, H-4GlcI), 3.29 (ddd, $J=2.5,4.5$ and $9.0 \mathrm{~Hz}, \mathrm{H}-5 \mathrm{GlcI}$ ), 3.69 (dd, $J=4.5$ and $11.5 \mathrm{~Hz}, \mathrm{H}-6 \mathrm{GGlcI}$ ), 3.84 (dd, $J=2.5$ and 11.5 $\mathrm{Hz}, \mathrm{H}-6 \mathrm{bGlcI})$. For ${ }^{13} \mathrm{C}$ NMR see Table 1.

3. HRMS, $m / z$ 741.452 [calculated for $\left.\mathrm{C}_{39} \mathrm{H}_{64} \mathrm{O}_{13}(\mathrm{M})^{+}\right]$; $579.3[\mathrm{M}-162]^{+} ;{ }^{1} \mathrm{H}$ NMR (aglycon) $\delta 4.41(1 \mathrm{H}, \mathrm{m}, \mathrm{H}-16)$, 3.68 (1H, m, H-3), 3.46 (1H, m, H-26a), 3.33 (1H, m, H-26b), 0.88 (3H, s, Me-19), 0.81 (3H, s, Me-18), 0.98 (3H, d, $\mathrm{H}-21), 1.10$ (3H, d, Me-27). (sugars) $\delta 4.38$ (d, J=7.4 Hz, H-1Gal), 3.51 (dd, J=7.4 and 9.0 Hz, H-2Gal), 3.53 (dd, $J=4.0$ and $9.0 \mathrm{~Hz}, \mathrm{H}-3 \mathrm{Gal}$ ), 4.08 (dd, $J=2.5$ and $4.0 \mathrm{~Hz}, \mathrm{H}-4 \mathrm{Gal}$ ), 3.58 (ddd, $J=2.5,2.5$ and $4.5 \mathrm{~Hz}, \mathrm{H}-5 \mathrm{Gal}$ ), 3.63 (dd, $J=4.5$ and $12.0 \mathrm{~Hz}, \mathrm{H}-6 \mathrm{aGal}$ ), 3.90 (dd, $J=2.5$ and $12.0 \mathrm{~Hz}, \mathrm{H}-6 \mathrm{bGal}), 4.53$ (d, J=7.5 Hz, H-1Glc), 3.29 (dd, $J=7.5 \mathrm{and} 9.0 \mathrm{~Hz}$, H-2Glc), 3.39 (dd, $J=9.0$ and $9.0 \mathrm{~Hz}, \mathrm{H}-3 \mathrm{Glc}$ ), 3.24 (dd, $J=9.0$ and $9.0 \mathrm{~Hz}, \mathrm{H}-4 \mathrm{Glc}$ ), 3.31 (ddd, $J=2.5,4.5$ and $9.0 \mathrm{~Hz}$, H-5Glc), 3.62 (dd, $J=4.5$ and $11.5 \mathrm{~Hz}, \mathrm{H}-6 \mathrm{aGlc}$ ), 3.93 (dd, $J=2.5$ and $11.5 \mathrm{~Hz}, \mathrm{H}-6 \mathrm{bGlc}$ ). For ${ }^{13} \mathrm{C}$ NMR see Table 1.

Antifungal assays. Whatever the tested product (extract, spirostanol fraction, individual glycosides) and the test microorganisms (yeasts, dermatophytes, filamentous fungi), the antifungal activity was evaluated with an agar dilution method, as previously described [12]. Yeast nitrogen base (Difco, Becton Dickinson, Sparks, MD) supplemented with $2 \%$ agar (Difco) was used as a test medium for yeasts. For dermatophytes and filamentous species, the tests were performed on Sabouraud dextrose agar (Difco). Eight reference yeast strains were used: Candida albicans ATCC 90029, Candida albicans Y0109, Candida albicans 38248, Candida tropicalis IP 1275-81, Candida parapsilosis ATCC 22019, Candida glabrata ATCC 90030, Candida kefyr Y 0106, Candida krusei ATCC 6258 and Candida lusitaniae CBS 6936. Dermatophytes (one isolate of each species: Trichophyton mentagrophytes, Trichophyton rubrum, Trichophyton soudanense, Microsporum canis, Microsporum gypseum, Epidermophyton floccosum) and Cryptococcus neoformans were all clinical isolates. Filamentous fungi (one isolate of each species: Aspergillus fumigatus, Aspergillus flavus, Scopulariopsis brevicaulis) were environmental isolates. All samples were dissolved in dimethyl sulphoxide (DMSO). The tested concentrations were $0.03 \mathrm{mg} / \mathrm{mL}$ for extract, and from 0.0625 to $10 \mu \mathrm{g} / \mathrm{mL}$ for pure compounds and the fractions. The final concentration of DMSO never exceeded $1 \%$. The minimum inhibitory concentration was defined as the first concentration showing no visible growth after the incubation time ( $48 \mathrm{~h}$ for the yeasts, 5-15 days for the dermatophytes and the filamentous fungi according to the species). The tests were performed in duplicate and in two separate experiments. Amphotericin B and ketoconazole (Sigma Chemical Co., St Louis, MO) were included in the assays as reference antifungal agents, for yeasts and filamentous fungi, and dermatophytes, respectively.

\section{CONCLUSION}

During the investigation six steroidal glycosides have been isolated from the seeds of Hyoscyamus niger L. for the first time. In this work the following structures have been suggested for three of them: compound 1 - 3-O$\beta$-D-glucopyranosyl-( $1 \rightarrow 2)-O-\beta$-D-glucopyranosyl-( $1 \rightarrow 4)-O-\beta$-D-galactopyranosyl-[ $(25 R)-5 \alpha$ - furostan- $3 \beta, 22 \alpha$, 26 -triol]- 26-O- $\beta$-D-glucopyranoside; compound 2 - 3-O- $\beta$-D-glucopyranosyl - $(1 \rightarrow 4)-O-\beta$-D-galactopyranosyl-[(25R) - $5 \alpha$ - furostan- $3 \beta, 22 \alpha, 26$-triol]-26-O- $\beta$-D-glucopyranoside; compound 3 - 3-O- $\beta$-D-glucopyranosyl - $(1 \rightarrow 4)-O-\beta$-D-

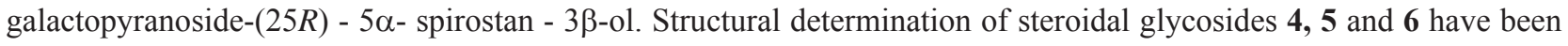
reported in previous work.

The results of biological tests revealed that antifungal steroidal glycosides are present in Hyoscyamus niger seeds. In vitro spirostanol fraction and glycosides showed a broad spectrum of antifungal activity. Only slight differences in their fungicidal profiles were observed. Not surprisingly, these compounds are monodesmosidic spirostanol glycosides 
like the majority of biologically active steroid saponins [9]. The antifungal properties of saponins are usually ascribed to their ability to complex with sterols in fungal membranes, thereby causing pore formation and loss of membrane integrity [13]. Interestingly, the tested extracts and compounds were inactive against C. lusitaniae ATCC 6936 although its sterol composition was shown to be similar to that of C. albicans ATCC 90029 [14]. Because antifungal agents must pass through the polysaccharidic cell wall first before reaching the target, this finding could be related to an unusual cell wall structure of this emerging yeast pathogen.

Thus, our study revealed the therapeutic potential of some spirostanol glycosides from Hyoscyamus niger seeds. Extract, which showed good activity against dermatophytes and which is readily available in large quantities, is a promising active principle for the topical treatment of dermatophytosis. Therefore, it is wortwhile to further study these antifungal compounds and, in a broad sense, the structure-activity relationships of more steroidal saponins to explore the therapeutic potential of this important class of natural products as antifungal leads for drug discovery.

\section{ACKNOWLEDGMENTS}

Financial support from INTAS (The International Association for the Promotion of Co-operation with Scientists from the New Independent States) is gratefully acknowledged. Also we are grateful to Prof. Carla Bassarello and Prof. Paola Montoro from the Department of Pharmaceutical Sciences, University of Salerno for the measurements of the mass spectra and NMR analysis.

\section{REFERENCES}

[1] Kirtikar, K.R.; Basu, B.D.; Indian Medicinal Plants, Reprint ed., Periodical Experts, New Delhi, 1975, 3, pp 1794-1795.

[2] Lunga, I.; Kintia, P.; Shvets, S.; Bassarello, C.; Pizza, C.; Piacente, S. Three spirostanol glycosides from the seeds of Hyoscyamus niger L., Chemistry Journal of Moldova, 2006, 1, pp 123-127.

[3] Dimoglo, A. S.; Choban, I. N.; Bersuker, I. B.; Kintia, P. K.; Balashova, N. N. Structure-activity correlations for the antioxidant and antifungal properties of steroid glycosides. Bioorg. Khim., 1985, 11, pp 408-413.

[4] Imai, S.; Fujioka, S.; Murata, E.; Goto, M.; Kawasaki, T.; Yamauchi, T. Bioassay of crude drugs and oriental crude drug preparations. XXII. Search for biologically active plant ingredients by means of antimicrobial tests: 4 . Antifungal activity of dioscin and related compounds. Takeda Kenkyusho Nenpo, 1967, 26, pp 76-83.

[5] Wolters, B. The share of the steroid saponins in the antibiotic action of Solanum dulcumata. Planta Med, 1965, 13, pp 189-193.

[6] Wolters, B. Antimicrobial activity of plant steroids and triterpenes. Planta Med, 1966, 14, pp 392-401.

[7] Sparg, S. G.; Light, M. E.; Staden J. V. Biological activities and distribution of plant saponins. J. Ethnopharmacol. 2004, 94, pp 219-243.

[8] Lacaille-Dubois, M. A.; Wagner, H. A review of the biological and pharmacological activities of saponins. Phytomedicine, 1996, 2, pp 363-386.

[9] Hostettman, K. A.; Marston, A. Saponins. Cambridge University Press: Cambridge, 1995.

[10] Shvets, S. A.; Naibi, A. M.; Kintia, P. K. Steroidal glycosides from Petunia hybrida seeds. II. Structure of petuniosides I, L and N. Inst. Genet., AN Respub. Moldova, Chisinau, Moldova. Khimiya Prirodnykh Soedinenii, 1995, 2, pp 247-52.

[11] Gutsu, E.V.; Kintia, P.K.; Lazur'evskii, G.V. Steroidal glycosides of Capsicum annuum root. Part II. Structure of capsicosides. Khimia Prirodnykh Soedinenii, 1987, 2, pp 242-246.

[12] Favel, A,; Steinmetz, M.D.; Regli, P. et al. In vitro antifungal activity of triterpenoid saponins. Planta Med, 1994, 60 , pp 50-53.

[13] Morrissey, J.P.; Osbourn, A. E. Fungal resistance to plant antibiotic as a mechanism of athogenesis. Microbiol. Mol., Biol. Rev., 1999, 63, pp 708-724.

[14] Peyron, F.; Favel, A.; Calaf, R. et al. Sterol and fatty acid composition of Candida lusitaniae clinical isolates. Antimicrob Agents Chemother, 2002, 46, pp 531-533. 